\title{
Hak-Hak Pendidikan Perempuan di Indonesia Perspektif Hukum Hak Asasi Manusia
}

\author{
Rinrin Rina \\ Penilik Pendidik Anak Usia Dini Kabupaten Sumedang \\ E-mail: rina.upi@gmail.com
}

\begin{abstract}
This article examines the injustice of women in Indonesia in education. This article is analyzed using a human rights law approach. Figures for women enter educational institutions are smaller than male figures. The higher the level of education, the smaller the average number of women enter. The Minister for the Role of Women (Menperta) said the backwardness of girls in education is illustrated in illiteracy where illiterate girls are more than three times that of illiterate boys. Though Normally-doctrinal, Islam firmly recognizes the concept of parallel between men and women. It is also reaffirmed in the 1948 Universal Declaration of Human Rights (DUHAM) that it is essential that all rights and freedoms shall be owned by everyone without discrimination, including non-discrimination on the basis of sex, men and women of equal degree. The focus of the study of this article is: First, how is the rights of women's education reviewed from the perspective of human rights law? Second, what are the obstacles in upholding gender equality in education?
\end{abstract}

Keywords: Education Rights, Women, Human Rights

\section{Abstrak}

Artikel ini mengkaji tentang ketidakadilan kaum perempuan di Indonesia di bidang pendidikan. Artikel ini di analisis dengan menggunakan pendekatan hukum hak asasi manusia (HAM). Angka perempuan masuk kelembaga pendidikan lebih kecil dibanding angka laki-laki. Semakin tinggi jenjang pendidikan, semakin kecil angka rata-rata masuk perempuan. Menteri Peranan Wanita (Menperta) mengatakan terbelakangnya anak perempuan dalam 
pendidikan tergambar dalam jumlah buta huruf dimana anak perempuan yang buta huruf lebih banyak tiga kali lipat dari anak laki-laki yang buta huruf. Padahal Secara normatifdoktrinal, Islam dengan tegas mengakui konsep kesejajaran antara laki-laki dan perempuan. Hal tersebut juga ditegaskan kembali dalam Deklarasi Universal Hak Asasi Manusia (DUHAM) 1948, didalamnya termuat bahwa hak dan kebebasan sangat perlu dimiliki oleh setiap orang tanpa diskriminasi, termasuk tidak melakukan diskriminasi berdasarkan jenis kelamin, laki-laki dan perempuan mempunyai derajat yang sama. Fokus kajian artikel ini adalah: Pertama, bagimanakah hak-hak pendidikan perempuan perspektif hukum hak asasi manusia (HAM)? Kedua, apa kendala-kendala dalam menegakkan keadilan gender dalam bidang pendidikan?

Kata Kunci: Hak-hak Pendidikan, Kaum Perempuan, Hak Asasi Manusia.

\section{A. Pendahuluan}

\section{Latar Belakang}

Pendidikan merupakan hak setiap orang, baik laki-laki dan perempuan berhak atas pendidikan yang sama. Falsafah negara menempatkan setiap orang untuk setara. Memiliki kesempatan yang sama dalam pendidikan, hal ini tercantum di dalam UUD 1945 hasil Amandemen "Setiap orang berhak mengembangkan diri melalui pemenuhan kebutuhan dasarnya, berhak mendapatkan pendidikan dan memperoleh manfaat dari ilmu pengetahuan dan teknologi, seni dan budaya, demi meningkatkan kualitas hidupnya dan demi kesejahteraan umat manusia". ${ }^{1}$

Selanjutnya Pasal 31 menyatakan bahwa "setiap warga negara berhak mendapatkan pendidikan, negara memprioritaskan anggaran pendidikan sekurang-kurangnya $20 \%$ dari anggaran pendapatan dan belanja daerah untuk memenuhi kebutuhan penyelenggaraan pendidikan nasional". Salah satu masalah besar untuk menyediakan

\footnotetext{
${ }^{1}$ Pasal 28 C (1) UUD 1945 hasil Amandemen.
} 
pendidikan berkualitas, khususnya anak perempuan, yaitu masih sedikitnya anggaran yang dialokasikan oleh pemerintah untuk sektor pendidikan. Anggaran Indonesia untuk pendidikan merupakan yang terendah di kawasan Asia Timur dan Pasifik, China, Malaysia, Filipina, dan Singapura, yang semuanya adalah pesaing utama Indonesia di bidang ekonomi.

Selain itu, UU No. 7 tahun 1984, menayatakan bahwa, Negara wajib melakukan langkah tindakan yang tepat: Salah satunya adalah mengubah pola tingkah laku sosial dan budaya laki-laki dan perempuan dengan maksud untuk mencapai penghapusan prasangka dan kebiasaan dan segala praktek lainnya yang berdasarkan inferioritas atau superioritas salah satu jenis kelamin atau berdasarkan peranan stereotib bagi laki-laki dan perempuan. ${ }^{2}$ Akan tetapi alih-alih negara bertanggung jawab atas derajat hak pendidikan yang sama tersebut, malahan negara mengeluarkan undang-undang yang didalamnya terdapat bias gender, yakni pembedaan antara laki-laki dan dan perempuan dalam pendidikan, hanya dikarenakan beda jenis kelamin, ${ }^{3}$ secara tidak langsung undang-undang ini telah bertentangan dengan UUD 1945 dan prinsip Hak Asasi Manusia (HAM). Selain itu data BPS mulai tahun 2000-2009. misalnya, menunjukan bahwa rata-rata angka perempuan masuk kelembaga pendidikan lebih kecil dibanding angka laki-laki. Semakin tinggi jenjang pendidikan, semakin kecil angka rata-rata masuk perempuan. Menteri Peranan Wanita (Menperta) mengatakan terbelakangnya anak perempuan dalam pendidikan tergambar dalam jumlah buta huruf dimana

\footnotetext{
${ }^{2}$ Pasal 5 UU No. 7 tahun 1984

${ }^{3}$ Lihat Pasal 1 Butir 4, Pasal 7 UU No.2/1989 tentang Pendidikan Nasional.
} 
anak perempuan yang buta huruf lebih banyak tiga kali lipat dari anak laki-laki yang buta huruf. ${ }^{4}$

Ini menjadi sangat jelas betapa Isu-isu perempuan yang dimapankan selama beberapa generasi hingga saat ini adalah sejalan dengan proses penguatan Islam tradisional (klasik), yang cenderung konservatif dan literal dalam memahami pesan-pesan keagamaan serta doktrin-doktrin yang ada, konstruk budaya patiarkhi yang mapan secara universal dan berlangsung selama berabad-abad, serta justifikasi atas otoritas yang didukung oleh perangkat Undang-undang negara, yang tentunya akibat ini semua sangat merugikan pihak kaum perempuan khususnya hak untuk memperoleh pendidikan. $^{5}$

Padahal Secara normatif-doktrinal, Islam dengan tegas mengakui konsep kesejajaran antara laki-laki dan perempuan. ${ }^{6}$ Hal tersebut juga ditegaskan kembali dalam Deklarasi Universal Hak Asasi Manusia (DUHAM) 1948, didalamnya termuat bahwa hak dan kebebasan sangat perlu dimiliki oleh setiap orang tanpa diskriminasi, termasuk tidak melakukan diskriminasi berdasarkan jenis kelamin, laki-laki dan perempuan mempunyai derajat yang sama. ${ }^{7}$ Dari sini setidaknya ada dua hal yang bisa disimpulkan: Pertama, pengakuan secara umum atas kesetaraan antara laki-laki dan

\footnotetext{
${ }^{4}$ http/www. Kesetaraan: Pendidikan Berbasis Jender/ghr,php akses 24 Februari 2011.

${ }^{5}$ Rusli, "The Tradisional and Women's Issues In The Shafi'ite Books of Islamic Jurisprudence", dalam Jurnal Asy-Syir'ah, Metode Penemuan Hukum Islam, vol. 38. No. II. (Yogyakarta: UIN Suka, 2004), hlm. 282.

${ }^{6}$ Sejarah menuliskan bahwa Muhammad SAW (abad VII) dengan lahirnya Islam sebagai "rohmatan lil 'alamin" pun telah memperjuangkan hak-hak asasi manusia, seperti dalam Piagam Madinah, yang disinyalir sebagai hak asasi pertama kali yang terealisasi dalam konstitusi, Khutbah haji Wada', dll. Namun, perjuangan ini malah banyak disalahtafsirkan sebaliknya menjadi pendeskreditan terhadap wanita. lihat Haifaa A. Jawad, The Right of Women in Islam, (Britain: Macmillan Press, 1998), hlm. 11.

${ }^{7}$ Saparinah Sadli, Hak Asai Perempuan Adalah Hak Asasi, Dalam Pemahaman Bentuk-Bentuk Tindak Kekerasan Terhadap Perempuan Dan Alternatif Pemecahannya, (Jakarta: Pusat Kajian Wanita dan Gender, Uiniversitas Indonesia Jakarta, 2000), hlm. 1.
} 
perempuan, tanpa membedakan jenis kelamin. Kedua, mengakuan atas kesejajaran hak dan keawajiban antara lakilaki dan perempuan dalam berbagai bidang. ${ }^{8}$

Namun sangat ironis, kenyataan historis-empiris justru cenderung sebaliknya, yakni status dan peran perempuan diberbagai masyarakat hingga sekarang ini pada umumnya masih berada pada posisi dan kondisi yang belum mengembirakan. Impikasi yang ditimbulkan bermacmmacam, diantaranya perempuan mengalami ragam ketidakadilan, marginalisasi, subordinasi, stereotip dan lain-lain. Dengan kondisi rill seperti itu wajar apabila kemudian status peran perempuan dinilai lebih buruk dimanapun dibelahan bumi ini. ${ }^{9}$

Istilah gender adalah suatu istilah yang digunakan untuk menggambarkan pembedaan antara laki-laki dan perempuan secara social. ${ }^{10}$ Gender adalah kelompok atribut dan prilaku yang dibentuk secara cultural yang ada pada laki-laki dan perempuan, jenis kelamin adalah biologi yang bersifat permanen, sedangkan gender adalah konstruksi social. ${ }^{11}$ Bentuk ketidak-adilan gender yang berupa proses marginalisasi perempuan adalah suatu pemiskinan atas satu jenis kelamin tertentu dalam hal ini disebabkan oleh perbedaan gender, ketidak-adilan gender menyebabkan ketidaknyamanan serta terbelenggunya hak kebebasan perempuan sebagai manusia (HAM). Oleh karena itu, segala bentuk ketidak-adilan, merupakan pelanggaran Hak Asasi Manusia (HAM), dan kajahatan terhadap martabat kemanusiaan serta bentuk diskriminasi yang wajib dihapuskan.

\section{${ }^{8}$ Zaitunah Subhan, Tafsir Kebencian: Studi Kasusu Gender dalam} Tafsir Qur'an, (Yogyakarta: LKiS, 1999), hlm. 4.

9 Penjelasan tentang jenis-jenis ketidak-adilan yang banyak dialami kaum perempuan ini; lihat, Mansour Faqih, Analsis Gender dan Transformasi Sosial, (Yogyakarta: Pustaka Pelajar, 1999), hlm. 12-23.

${ }^{10}$ WJS, Poerwadarminta, Kamus Umum Bahasa Indonesia, cet. Ke-5, (Jakarta: Balai Pustaka, 1976)

${ }_{11}$ Margert Mead, Sex and Temperament in Three Primitive Societies, tp., (1935), hlm. 21. 
Membicarakan tentang hak asasi manusia (HAM) berarti membicarakan dimensi kehidupan manusia. HAM ada bukan karena diberikan oleh masyarakat dan kebaikan dari negara, melainkan berdasarkan martabatnya sebagai manusia. ${ }^{12}$ Hak asasi manusia (HAM) adalah hak-hak yang dimiliki manusia semata-mata karena ia manusia. Umat manusia memilikinya bukan karena diberikan kepadanya oleh masyarakat atau berdasarkan hukum positif, melainkan semata-mata berdasarkan martabatnya sebagai manusia. Dalam arti ini, maka meskipun setiap orang terlahir dengan warna kulit, jenis kelamin, bahasa, budaya dan kewarganegaraan yang berbeda-beda, ia tetap mempunyai hak-hak tersebut. Inilah sifat universal dari hak-hak tersebut. Selain bersifat universal, hak-hak itu juga tidak dapat dicabut (inalienable). ${ }^{13}$ Pengakuan atas eksistensi manusia menandakan bahwa manusia sebagai makhluk hidup adalah ciptaan Tuhan Yang Maha Kuasa, yang patut memperoleh aprisisasi secara positif. $^{14}$

Anggapan bahwa perempuan lebih rendah dari pada lakilaki memunculkan doktrin ketidak-adilan serta ketidaksetaraan antara laki-laki dan perempuan yang kemudian melahirkan nilai-nilai patiarkhi. ${ }^{15}$ Konstruk budaya patiarkhi yang mapan secara universal dan berlangsung selama berabad-abad hal tidak lagi dipandang sebagai ketimpangan, bahkan ini diklaim sebagai "Fakta Ilmiah" "16 hal ini berimbas

12 Franz Magnis Suseno, Etika Politik: Prinsip-Prinsip Moral Dasar Kenegaraan Modern (Jakarta: PT Gramedia Pustaka Utama, 2001), hlm. 121.

${ }^{13}$ Suparman Marzuki dan Eko Riyadi (Penyunting/Editor), Hukum Hak Asasi Manusia (Yogyakarta: Pusat Studi Hak Asasi Manusia Universitas Islam Indonesia PUSHAM UII, 2008), hlm. 7.

14 Majda El-Muhtaj, Hak Asasi Manusia dalam Konstitusi Indonesia: Dari UUD 1945 Sampai dengan Amandemen UUD 1945 Tahun 2002 (Jakarta: KENCANA, 2009), hlm.56.

${ }^{15}$ Sahbana, "Wanita Indonesia dalam Keluarga Persepektif Islam, dalam, Jurnal Ilmu Syari'ah, Keadilan Gender dalam Syari'at Islam, (Yogyakarta: UIN Press, 2001), hlm. 141.

${ }^{16}$ Siti Ruhaini Dzuhayatin, Teologi Feminis Islam "Suatu Refleksi Pergulatan Pemikiran Feminis dalam Wacana Islam di Indonesia, Jurnal Teologi Gema, edisi 55, hlm. 109. 
ketidak-adilan pada perempuan, salah satunya adalah masalah hak-hak perempuan dalam bidang pendidikan.

Melihat fakta diatas, maka sudah menjadi kewajiban pemerintah untuk membuat suatu kebijakan atau politik hukum guna mengembalikan kembali hak-hak asasi kaum perempuan, selain kebijakan pemerintah juga harus dilakukan suatu upaya-upaya kesetaraan antara laki-laki dan perempuan, kemudian disosialisasikan secara luas diseluruh lapisan masyarakat di seluruh dunia. Hal tersebut agar terwujud sebuah kesetaran dan keadilan baik bagi perempuan dan laki-laki. Kasus-kasus berikut warisan budaya mapun warisan orde baru tersebut menjadi beban dan tanggung jawab pemerintah untuk menyelesaikannya, oleh karena itu diperlukan politik hukum HAM baru. Suatu studi politik hukum dalam kaitan untuk memahami perkembangan hukum HAM di Indonesia tersebut sangat penting, karena dengan melakukan studi tersebut akan dapat diketahui corak kebijakan legeslasi HAM pada tiap kurun waktu tertentu.

\section{Rumusan Masalah}

a. Bagimanakah hak-hak pendidikan perempuan perspektif hukum hak asasi manusia (HAM)?

b. Apa kendala-kendala dalam menegakkan keadilan gender dalam bidang pendidikan?

\section{B. Potret Pendidikan Perempuan di Indonesia}

Perempuan mempunyai peran penting dalam kehidupan. Perempuan adalah pendidik anak yang akan mengendalikan jalur kehidupan mereka selanjutnya. Atas dasar itu, untuk meningkatkan kualitas dan memperbaiki kedudukan perempuan diperlukan pendidikan khusus kaum perempuan yang diajarkan oleh kaum perempuan sendiri. Dalam hal ini perlu adanya upaya untuk meningkatkan kemampuan kaum 
perempuan, baik di bidang intelektual, kepribadian ataupun keterampilan

Pendidikan yang mencerdaskan bangsa serta kompetitif dalam dunia global mutlak diperlukan oleh seluruh komponen bangsa dalam menghadapi semua persoalan di semua lini kehidupan. Artinya angka putus sekolah yang tinggi serta masih tingginya angka diskriminasi rendahnya angka lulusan perguruan tinggi pada kaum perempuan serta masih tingginya angka buta huruf di kalangan perempuan Indonesia-serta kekerasan rumah tangga perempuan harus segera di reformasi. Tanpa itu posisi penting dalam pembangunan nasional tidak akan dirasakan kaum perempuan. ${ }^{17}$ Pendidikan adalah hak setiap manusia, oleh karena itu segala macam bentuk yang menghambat tercapainya hak pendidikan tersebut baik faktor budaya (patriarkhisme) maupun yang lain harus segera dihapuskan. Tingkat kesetaraan dalam pendidikan bagi laki-laki maupun perempuan khususnya di Indonesia masih sangat ketara, pendidikan bagi perempuan di Indonesia masih sangat rendah dibandingkan kaum laki-laki. Jumlah anak perempuan yang tidak meneruskan pendidikan lanjutan pertama dan menengah lebih besar daripada murid laki-laki, sehingga bila tidak ada upaya untuk memperbaikinya maka usaha pemerintah untuk menekan kemiskinan tidak akan berhasil. Pemerintah Indonesia masih perlu menjadikan pendidikan sebagai prioritas jika negara ini ingin pembangunannya lebih berhasil.

Kantor Meneg PP mensinyalir terdapat bias gender pada UU No. 2 tahun 1989 tentang Pendidikan Nasional. Meskipun hanya pada beberapa pasal, yang berkenaan dengan jenis penddidikan yang dikelompokkan sesuai dengan

17 Hasbullah, Sejarah Pendidikan Islam di Indonesia Lintas Sejarah Pertumbuhan dan Perkembangan, (Jakarta: Raja Grafindo Persada, 1999), hlm. 34. 
sifat dan kekhususan tujuannya. ${ }^{18}$ Walaupun hanya beberapa pasal yang bias gender, dengan justifikasi atas otoritas yang didukung oleh perangkat Undang-undang negara tersebut, mengakibatkan tindak-adilan bagi kaum perempuam di dalam pendidikan.

Data riset Education Watch tahun 2009-2010 menyebutkan bahwa kecenderungan realitas tidak meneruskan sekolah bagi anak- anak dari keluarga miskin makin meningkat persentasenya. Data anak-anak dari keluarga miskin yang jebol sekolah ketika duduk di bangku sekolah dasar meningkat menjadi $24 \%$, sedangkan yang tidak melanjutkan ke bangku sekolah menengah pertama menjadi $21,7 \%$. Sementara anak-anak usia sekolah dari keluarga miskin yang jebol sekolah ketika memasuki bangku usia sekolah menengah mencapai $18,3 \%$, dan yang tidak meneruskan ke jenjang pendidikan sekolah menengah atas dari sekolah menengah pertama mencapai $29,5 \%$. Ironisnya, kebanyakan anak- anak usia sekolah dari keluarga miskin yang gagal melanjutkan sekolah dari jenjang SD ke SMP atau dari SMP ke SMA mayoritas (72,3\%) adalah siswa perempuan.

Anak-anak perempuan usia sekolah yang tidak meneruskan sekolah selain karena minimnya biaya pendidikan dari keluarga, juga karena masih terjerat cara pandang patriarkis orang tua. Orang tua anak-anak perempuan usia sekolah dari keluarga miskin menganggap anak-anak perempuan mereka tidak usah melanjutkan sekolah. Lebih baik anak perempuannya langsung dinikahkan atau didorong bekerja di sektor publik sebagai pembantu

${ }^{18}$ Riant Nugroho, Gender dan Adminstarsi Publik "StudynTentang Kualitas Kesetaraan Gender dalam Adminstrasi Publik Indonseian Pasca Reformasi 1998-2002, (Yogyakarta: PUSTAKA PELAJAR, 2008), hlm. 227. 
rumah tangga atau buruh informal. ${ }^{19}$ Ini menunjukan bahwa rata-rata angka perempuan masuk kelembaga pendidikan lebih kecil dibanding angka laki-laki. Semakin tinggi jenjang pendidikan, semakin kecil angka rata-rata masuk perempuan.

Data kualitatif diatas memberikan gambaran bahwa semakin tinggi tingkat pendidikan, semakin ada kesenjangan partisipasi antara laki-laki dan perempuan. Melihat fakta diatas, diperlukan kebijakan dan langkah-tindak yang tepat untuk mengatatasi kesenjangan tersebut. Sehingga hak asasi untuk mendapat pendidikan bagi perempuan dapat dipenuhi.

Kesempatan yang sangat kecil dari data diatas merupakan salah satu ketimpangan pendidikan bagi perempuan. Ketimpangan lain adalah segregasi (pengecualian) yang lebih sering menistakan perempuan, stereotipe yang menempatkan perempuan hanya untuk jenis pendidikan tertentu dan yang lebih diperparah adalah kurikulum dan meteri pendidikan yang masih dilestarikan nilai-nilai ketidak-adilan bagi perempuan. Ketimpangan ini merupakan tanggung jawab semua orang, terutama negara terhadap rakyatnya. Masyarakatpun, dengan kulturnya yang masih tidak adil terhadap perempuan, ikut bertanggung jawab dalam melestarikan ketimpangan pendidikan perempuan.

Kesadaran gender belum memiliki oleh seluruh masyarakat, tak heran jika program-program pembangunan diberbagai sector belum mencerminkan kesadaran tersebut. Dalam praktek pendidikan, menunjukkna bahwa guru juga cenderung memenuhi gambaran stereotype teradap murid perempuan. Akibatnya kesenjangan semakin melebar. Defisit kemampuan yang ada pada siswa perempuan bukan diberi perbaikan (remideal) yang memadai, tetapi menyerah kepada pemenuhan gambaran akan kelemahan-kelemahan yang sudah dicapkan kepada siswa perempuan. Pandangan orang

\footnotetext{
19 http/www. Kesetaraan: Jender/ghr,php,akses 19 Oktober 2010

Pendidikan Berbasis
} 
tua terhadap anak laki-laki dan perempuan masih amat kuat mencerminkan sifat "Male Dominant" bukan mitra sejajar sehingga jika dihadapkan kepada pilihan, betapapun tingginya kemampuan anak perempuan tersebut, priporitas pendidikan akan tetap diberikan kepada anak lai-laki.

Bangsa ini harus yakin bahwa generasinya mampu hidup sejajar bila kita buka peluang pendidikan dan pemberdayaan itu bisa berjalan seiring sebagai agenda penyelesaian masalah bangsa secara tuntas. Dan perempuan yang berjasa dalam merintis kemerdekaan juga bisa dirasakan perannya dalam pembangunan negara ini melalui perjuangan menentaskan kaumnya yang masih banyak yang tertinggal maupun termarjinalkan dalam pembangunan yang belum berpihak pada perempuan selama ini. Artinya hak-hak yang sama dalam pembangunan bangsa dan negara ini tidak boleh dibangun secara parsial.

\section{Hak Pendidikan Perempauan Perspektif Hak Asasi Manusia}

Pendidikan adalah aset bangsa, pendidikan juga mencirikan pembangunan karakter bangsa. Pendidikan yang berkualitas akan serta merta melahirkan kemajuan dan peradaban bangsa. Sebaliknya pendidikan yang buruk akan berimplikasi negatif bagi jalannya roda pemerintahan dan ketersediaan partisipasi publik yang cerdas. Begitu sangat pentingnya keberadaan pendidikan, maka terpenuhinya hakhak atas pendidikan merupakan hak asasi manusia (HAM). ${ }^{20}$

Sudah mafhum bahwa hak atas pendidikan adalah HAM. Masyarakat Internasional sepakat bahwa pendidikan menempati prioritas utama dalam mengokohkan eksistensi diri manusia. ${ }^{21}$ Dalam United Nations, dinyatakan bahwa

20 Majda El-Muhtaj, Dimensi-Dimensi HAM “Mengurai Hak Ekonomi, Sosial dan Budaya, (Jakarta: Rajawali Press, 2009), hlm. 162.

${ }^{21}$ Lihat Pasal 26 DUHAM. 
pendidikan harus dijatuhkan kearah perkembangan pribadi yang seluas-luasnya serta memperkokoh rasa penghargaan terhadap hak asasi manusia (HAM), dan kebebasan asasi, pendidikan harus menggalakkan saling pengertian, toleransi dan persahabatan diantara semua bangsa, kelompok ras maupun bangsa, tidak mebedakan jenis kelamin, serta harus memajukan memajukan Perserikatan Bangsa-Bangsa dalam memelihara perdamaian. $^{22}$

Dalam tulisannya Prof. M. Sayed, dinyatakan bahwa: Hak atas pendidikan merupakan suatu kesatuan bangunan sitem hukum HAM Internasional. Dalam upaya memajukan hak atas pendidikan, negara wajib memajukan nilai-nilai HAM dalam kurikulum pendidikan yang selaras dengan konstruk HAM nasional maupun internasional. ${ }^{23}$

Dalam Pasal 13 ayat (2) ICESCR juga ditegaskan bahwa pemerintah untuk segera mengambil langkah-langkah cerdas dalam pemenuhan hak atas pendidikan, akses terhadap keseluruhan jenjang pendidikan harus menjadi perhatian pemerintah. Sebagai HAM, hak atas pendidikan memberikan arti penting bagi upaya pemenuhan HAM secara luas, penegasan ini penting artinya bagi upaya pembangunan kesadaran kolektif terhadap pemenuhan hak atas pendidikan. Hak atas pendidikan berkaitan erat dengan hak sipil dan politik serta ekonomi, sosial dan budaya. Hak atas pendidikan secara efektif memberikan pengaruh langsung bagi peningkatan dan pemenuhan hak-hak lainnya, pemenuhan terhadap hak pendidikan adalah pemenuhan bagi jati diri dan kemartabatan manusia. ${ }^{24}$

22 United Nations, Human Raights; A Compilation of Internastional Instruments, vol. 1 (New York: United Nations, 20002), hlm. 5.

${ }^{23}$ M.H., Syed, Human Raights; the Global Perspektiv, (New Delhi, Reference Press, 2003), hlm. 308.

${ }^{24}$ Coomans, "The Core Content of the Raights." dalam Brand dan Russel (ed.), Exploring teh Core Content of Socio-Economic Raghts, 
Harus diakui bahwa persoalan ketersediaan akses pendidikan di negara Indonesia masih terbilang rendah. Kini, pendidikan yang berkualitas sering diasumsikan dengan pendidikan yang mahal, sekolah secara berlahan menjadi ajang kemewahan. Pendidikan yang mencerdaskan bangsa serta kompetitif dalam dunia global mutlak diperlukan oleh seluruh komponen bangsa dalam menghadapi semua persoalan di semua sendi kehidupan. Artinya angka putus sekolah yang tinggi serta masih tingginya angka diskriminasirendahnya angka lulusan perguruan tinggi pada kaum perempuan serta masih tingginya angka buta huruf di kalangan perempuan Indonesia-serta kekerasan rumah tangga perempuan harus segera di reformasi. Reformasi yang paling mendasar yaitu memberdayakan kaum perempuan itu sendiri. Pemberdayaan itu harus mampu menyentuh akar persoalan yang dihadapi kaum perempuan. Bidang-bidang paling strategis yang membuat perempuan termarjinalkan harus diangkat secara tuntas.

Bangsa ini harus yakin bahwa generasinya mampu hidup sejajar bila kita buka peluang pendidikan dan pemberdayaan itu bisa berjalan seiring sebagai agenda penyelesaian masalah bangsa secara tuntas. Dan perempuan yang berjasa dalam merintis kemerdekaan juga bisa dirasakan perannya dalam pembangunan negara ini melalui perjuangan menentaskan kaumnya yang masih banyak yang tertinggal maupun termarginalkan dalam pembangunan yang belum berpihak pada perempuan selama ini. Artinya hak-hak yang sama dalam pembangunan bangsa dan negara ini tidak boleh dibangun secara parsial. ${ }^{25}$

Konstruksi pemikiran perempuan dan laki-laki yang bias gender dalam pembangunan yang kita lakukan dalam

South African and International Perspectivis, ( Pretoria, Protea book House, 2002), hlm. 160.

${ }^{25}$ http/www. Kesetaraan: Pendidikan Berbasis Jender/ghr,php, akses 24 Februari. 2017 
menentukan kebijakan negara dalam semua sektor harus dihilangkan. Pemikiran itu ternyata hanya menjadikan kita menjadi bangsa yang kerdil dalam pentas global. Dan itupula yang ikut membuat hak-hak perempuan sulit berkembang dalam berhadapan dengan ekses negatif budaya kompetisi pasar bebas. Sudah waktunya generasi bangsa yang tercerahkan itu lahir menjadi penyelamat bangsa yang terpuruk karena keterbelakangan. Dan itu bisa hilang bila bangsa ini percaya pada peran lembaga pendidikan dalam membangun bangsa yang berkualitas dan maju. negara kita mayoritas perempuan dan paling rentan masalah harus bisa segera diangkat harkat dan martabatnya untuk bisa berkontribusi membangun bangsa ini secara bersamasama. Dan pendidikan yang belum menyentuh seluruh lapisan masyarakat yang ada harus kita bangun dan kita buka seluasluasnya di negara ini.

Selain itu, dalam kajian studi islam, ada beberapa teks hadis yang dari sisi sanad sebenarnya adalah lemah, yang menghambat aktivitas pendidikan perempuan harus segera dihentikan pengajaran dan periwayatannya. Apabila teks-teks hadis tersebut tertulis dalam kitab-kitab maupun buku kurikulum, ia harus dibaca ulang dengan penegtahuan yang memadai, seperti hadis yang memerintahkan perempuan untuk selamanya tinggal di dalam rumah untuk mengikuti perintah suaminya dan melayani segala kebutuhannya. ${ }^{26}$

Teks hadis yang seperti ini akan banyak menghambat perempuan untuk memperoleh pengetahuan dan pendidikan. Beberapa teks hadis yang sejenis juga harus dikritik dan dimaknai ulang. Seperti juga hadis pelarangan perempuan untuk terlibat langsung aktivitas dimasjid. Pelarangan perempuan untuk shalat dimasjid, berarti penghambatan

${ }^{26}$ Hadis tersebut dikutip oleh al-Ghozali (w. 505H) dalam nagnun opus-nya Ihya' Ulu>m ad-di>n dan Imam Nawawi (w. 1315H) dalam kitab Uqu>d al-Lujjain. Lihat, FK3, Wajah Baru Relasi Suami Isteri: Telaah Kitab 'Uqu>d l-Lujjayn, 2001), hlm. 126-128. 
terhadap perempuan untuk memperoleh pengetahuan, pendidikan dan informasi. Karena itu masjid bagi umat Islam adalah pusat pengetahuan, informasi termasuk pendidikan, disamping sarana untuk ibadah ritual. Contoh teks Hadis yang menghambat kaum perempuan untuk aktif dimasjid serta ibadah dimasjid adalah:

"Shalat perempuan didalam rumahnya lebih baik dari pada shalatnya di dalam masjid" (Riwayat al-Baihaqi, Sunan al-Qubra, juz III, hlm. 132).

Sekalipun sanad teks ini secara sanad adalah shahih (kuat dan diterima), seperti yang dinyatakan Ibn Khuzaimah, Ibn hibban, al-Hasytamy dan as-Suyuthi, tetapi ia menyalahi teks-teks hadis lain yang lebih kuat dan bertentangan dengan fakta-fakta sejarah. Dalam teks lain, yang diriwayatkan Bukhari-Muslim dan at-Turmudzi, Nabi SAW menyatakan: "Apabila isterimu meminta izin untuk pergi ke masjid di malam hari, maka janganlah dihalangi. Atau: "Janganlah menghalangi para perempuan yang ingin pergi ke masjid Allah". ${ }^{27}$

Dengan argumentasi ini, dan beberapa argimentasi yang lain, bahwa hadis pelarangan perempuan untuk pergi ke masjid adalah lemah dan tidak bisa dipertanggung jawabkan. ${ }^{28}$ Saat ini pelarangan seorang khususnya perempuan untuk pergi kemasjid, atau tempat-tempat public yang lain yang mendatangkan manfaat adalah bertentangan dengan hak asasi seseorang tersebut untuk memperoleh manfaat pengetahuan dan informasi, khususnya adalah hak pendidikan kaum perempuan. Pendidikan adalah hak bagi setiap orang, baik laki-laki maupun perempuan. Dalam bahasa hadis: "Menuntut ilmu adalah kewajiban bagi setiap muslim ${ }^{, 29}$

\footnotetext{
${ }^{27}$ Lihat: Ibn al-Atsir, juz XI, hlm. 467, nomor hadis 8698

${ }^{28}$ Ali Bin Ahmad w. 456 H/1064M. FK3, 2001, hlm. 115.

${ }^{29}$ Riwayat ibn Majjah, al-Baihaqi dan Ibn Abd al-Barr.
} 
Pendidikan merupakan kunci terwujudnya keadilan gender dalam masyarakat, karena pendidikan disamping merupakan alat untuk menstranfer norma-norma masyarakat, penegetahuan dan kemampuan mereka, juga sebagai alat untuk mengkaji dan menyampaikan ide-ide dan nilai-nilai baru. Dengan kata lain lembaga pendidikan merupakan sarana formal untuk mensosialisasi sekaligus menstransfer nilai-nilai dan norma-norma yang berlaku dalam masyarakat, termasuk nilai dan norma gender. Nilai dan norma tersebut ditransfer secara lugas mapun secara tersembunyi baik melalui buku-buku teks yang digunakan mapun pada suasana dan proses pembelajaran. ${ }^{30}$

\section{Kendala-kendala dalam Penegakan Kesetaraan Gender Pendidikan}

Kendala pertama adalah kendala Internal. Kendala ini berasal dari perempuan sendiri, walupun tidak dapat dipungkiri bahwa struktur budaya, lingkungan, maupun budaya stereotip dalam masyarakat menjadi faktor-faktor penyebabnya, perempuan sering kali sukar untuk menemukan indentitasnya dirinya secara pribadi, akibat budaya yang menyebabkan perempuan menemui kesulitan untuk menghilangkan perasaan malu dan bersalah. Ambisi pribadi yang didorong oleh emosi yang tidak terkendali akan mewujudkan fikiran yang tidak sehat, serta pandangan stereotip yang telah merasuk kedalam jiwa mental perempuan, menyebabkan para kaum perempuan kerapkali tertinggal dalam pengambilan keputusan. ${ }^{31}$

Dunia pendidikan serta politik kerapkali identik dengan dunia laki-laki, karena serat dengan persaingan dan

${ }^{30}$ Susilaningsing dan Agus Muh. Najib (Ed.), Kesetaraan Gender di Perguruan Tinggi Islam, (Yogyakarta: UIN Suka dan McGill-IAIN, 2004), hlm. 28-29.

${ }^{31}$ A. Nunuk P. Murti, Getar Gender, (Magelang: Indonesia Tera, 2003), hlm. 52. 
kecenderungan keras untuk terlibat didalamnya, selain iteligensi yang cukup diperlukan juga keberanian dan mental yang kuat, sedangkan secara umum perasaan perempuan, perempuan mempunyai karakter sebagai makhluk pemelihara yang melayani segala kebutuhan hidup, khusus lewat lingkungan keluarga, oleh karenanya perempuan bermental sebagai makhluk yang dependen, yang kurang berani dalam menerima, apabila merebut kekuasaan, selain itu, berbagai kelainan jiwa mudah hinggap dalam diri perempuan, seperti ketersaingan diri, dan sikap tertutup yang ekstrim.

Kendala kedua adalah kendala eksternal. Kendala eksternal adalah kendala yang menghambat yang berasal dari luar diri kelompok perempuan, factor ekternal ini dapat menjadi ancaman yang sangat serius. Misalnya: Agama dan masyarakat. Mayoritas penduduk Indonesia meyakini bahwa suami adalah pemimpin keluarga. Al-Qur'an telah menyatakan bahwa kaum laki-laki (suami) adalah pemimpin bagi kaum perempuan (istri), dari ayat ini posisi kaum lakilaki lebih tinggi dibandingkan kaum perempuan, yang membenarkan suami untuk melakukan pemukulan terhadap istri. $^{32}$ Banyak ulama tafsir menyatakan bahwa perlu menakanan ulang terhadap ayat tersebut dan perlu pemaknaan ayat secara utuh terhadap ayat tersebut.

Budaya masyarakat Indonesia yang dilandasi agama, adalah budaya patriarkhis yang cenderung menempatkan laki-laki dalam posisi lebih tinggi dibandingkan kaum perempuan. Cara berfikir patriarkhi ini telah mengakumulasi terciptalah cara berfikir ini masuk kedalam segala aspek kehidupan, sehingga menghegomoni dan dianggap wajar, alamiah dan dianggab kodrat. ${ }^{33}$ Oleh karena itu, perempuan

${ }^{32}$ Lihat Q. S. an-Nisa' [4]: 34

${ }^{33}$ Imbas yang dirasakan oleh kau perempuan adalah: Misalnya ketidak-adilan pembagian kerja dalam keluarga antara bapak dengan ibu, dimana peran iburumahtangga sangat berat skali, para ibu rumahtangga bertanggung-jawab pada seluruh pekerjaan domestic dan untuk memnuhi 
merasakan imbas yang sangat besar, yaitu dalam bidang pendidikan, pendidikan dianggab tidak layak bagi kaum perempuan, karena tugas perempuan adalah sektor domestik saja bukan publik.

Selain faktor agama dan masyarakat diatas, kebijakankebijakan pemerintah juga menjadi kendala dalam masalah penegakan keadilan gender dalam pendidikan, salah satunya adalah dalam ketentuan di dalam Undang-undang pendidikan telah ditemukan ketidak-adilan gender, hal tersebut terdapat di beberapa Pasal yang disinyalir bias gender, yaitu pada UU. No. 2 Tahun 1989 tentang Pendidikan Nasional. Contoh lainnya adalah kebijakan mengacu pada peran perempuan dan laki-laki sebagaimana didefinisikan dalam Undangundang No. 1 tahun 1974 tentang Perkawinan, dalam Undang-undang tersebut dinyatakan bahwa suami adalah kepala keluarga, dan ibu adalah rumah tangga. Penegasan ini merupakan pengetatan fungsi-fungsi istri dan fungsi-fungsi suami secara tegas. Artinya, pasal ini melegitimasikan secara ekplisit pembagian peran berasarkan jenis kelamin, yang telah menyebabkan kebanyakan kaum perempuan di Indonesia memandang dunia publik adalah dunia laki-laki, akibatnya perempuan lebih lambut terjun kedunia publik dan lebih lambat dalam membangun jaringan kepada calon pemilihnya. Selain pasal tersebut diatas, pasal lain tentang persyaratan dalam hal seseorang suami akan beristri lebih dari seorang (poligami) juga merupakan kebijakan

pekerjaan itu tanpa ada batas waktunya, namun yang menjadi keperhatinan adalah dalam realita kehidupan ternyata ketidak adilan gender ini dilakukan secara tidak sadar karena hanya berdasarkan kebiasaan semata (lebih epat dikatakan bahwa terjadinya ketidak adilan berlangsung karena ketidaktahuan) yang secara social dianggap sebagai sesuat yang normal, wajar dan bersifat kodrati. Lihat, Santi Wijaya Hesti Utami, Kesetaraan Gender "Langkah Menuju Demokratisasi Desa, (Yogyakarta: IP. Lappera Indonesia, 2001), hlm. 6-7. 
pemerintah yang tentunya perlu direfisi kembali demi kesetaraan dan keadilan bagi laki-laki dan perempuan. ${ }^{34}$

Adapun penyebab bias gender dalam pendidikan Islam dipengaruhi oleh tiga aspek, yaitu: partisipasi, akses, dan kontrol. Namun, tidak semua aspek yang disebutkan dapat dipaksakan untuk menjelaskan masing-masing bias gender yang terjadi secara empiris dalam bidang pendidikan. Dengan kata lain faktor-faktor penyebab bias gender akan sangat tergantung dari situasinya masing- masing. ${ }^{35}$

Adapun faktor-faktor yang menjadi penyebab bias gender berkaitan dengan perolehan kesempatan belajar pada setiap jenjang pendidikan adalah:

1. Perbedaan angkatan partisipasi pendidikan pada tingkat SD/Ibtidaiyah sudah mencapai titik optimal yang tidak mungkin diatasi hanya dengan kebijakan pendidikan, sehingga perbedaan itu menjadi semakin sulit ditekan ke titik yang lebih rendah lagi. Kesenjangan ini lebih dipengaruhi oleh faktor-faktor struktur karena fasilitas pendidikan SD sudah tersebar relatif merata. Faktorfaktor struktural itu di antaranya adalah nilai-nilai sosial budaya, dan ekonomi keluarga yang lebih menganggap pendidikan untuk anak laki-laki lebih penting dibandingkan dengan perempuan. Faktor ini berlaku terutama di daerah-daerah terpencil yang jarang penduduknya serta pada keluarga-keluarga berpendidikan rendah yang mendahulukan pendidikan untuk anak laki- laki.

2. Pada tingkat SLTP/Tsanawiyah dan SMU/Madrasah Aliyah perbedaan angka partisipasi menurut gender lebih banyak terjadi pada daerah-daerah yang masih kekurangan fasilitas pendidikan, terutama di daerah-

${ }^{34}$ Lihat Pasal 4 UU. No. 1 tahun 1974 tentang Perkawinan.

${ }^{35}$ Suryadi, Ace \& Ecep Idris. Kesetaraan Gender dalam Bidang Pendidikan. Cet. I. (Bandung: genesindo, 2004), hlm. 27. 
daerah pedesaan dan luar Jawa. Faktor penyebab bias gender pada tingkat SLTP ke atas relatif lebih kecil dipengaruhi oleh nilai-nilai sosial budaya dan ekonomi keluarga karena siswa dan mahasiswa yang datang dari keluarga sosial ekonomi tinggi sudah lebih besar proporsinya. Dengan demikian, pengadaan dan distribusi sumber-sumber pendidikan SLTP, SLTA dan Perguruan Tinggi masih menjadi faktor penting untuk mengurangi bias gender dalam pendidikan.

Adapun faktor-faktor yang mempengaruhi bias gender yang berhubungan dengan akses dalam proses pendidikan adalah sebagai berikut:

1. Partisipasi perempuan dalam proses pengambilan keputusan pendidikan sangat rendah karena akses perempuan juga masih dirasakan rendah dalam menempati jabatan-jabatan birokrasi pemegang kebijakan Proporsi kepada sekolah perempuan secara konsisten masih kecil dibandingkan dengan laki-laki pada setiap jenjang pendidikan. Perempuan pemegang jabatan struktural, dari tingkatan strategis sampai operasional jauh lebih rendah daripada lawan jenisnya. Oleh karena itu, banyak kebijakan pendidikan kurang sensitif gender, yang akan berdampak luas terhadap berbagai dimensi bias gender dalam bidang pendidikan.

2. Laki-laki lebih dominan dalam mempengaruhi isi kurikulum sehingga proses pembelajaran cenderung bias laki-laki (Male Bias). Fenomena ini dapat diamati dari buku-buku pelajaran yang sebagian besar penulisnya adalah laki-laki. Penulis buku laki-laki sangat dominan. Dalam hal ini telah dikritisi oleh para teori feminisme.

3. Isi buku pelajaran yang membahas status perempuan dalam masyarakat akan banyak memberikan pengaruh terhadap kesenjangan gender dalam proses pendidikan. Muatan dari sebagian buku- buku pelajaran (khususnya IPS, PPKN, Pendidika Jasmani, Bahasa dan Sastra 
Indonesia, Kesenian dan sejenisnya) yang berhasil diamati cenderung kurang berwawasan gender khususnya berkaitan dengan konsep keluarga atau peran perempuan dalam keluarga yang telah lama dipengaruhi oleh cara berpikir tradisional, bahwa laki-laki adalah pemegang fungsi produksi sedangkan perempuan memegang fungsi reproduksi.

Faktor-faktoryang mempengaruhi penyebab bias gender dalam bidang kurangnya kontrol kebijakan pendidikan adalah:

1. Faktor kesenjangan antar gender dalam bidang pendidikan jauh lebih dominan laki-laki. Khususnya dalam lembaga birokrasi di lingkungan pendidikan sebagai pemegang kekuasaan atau kebijaksanaan, maupun dalam jabatanjabatan akademis kependidikan sebagai pemegang kendali pemikiran yang banyak mempengaruhi kebijakan pendidikan. Keadaan ini akan semakin bertambah parah jika para pemikir atau pemegang kebijaksanaan pendidikan tersebut tidak memiliki sensitivitas gender.

2. Khusus pada kebijaksanaan pendidikan, khususnya menyangkut sistem seleksi dalam pendidikan. Kontrol dalam penerimaan karyawan terutama di sektor swasta sangat dirasakan bias gender. Kenyataan menunjukkan bahwa jika suami istri berada dalam salah satu perusahaan, misalnya Bank, baik milik pemerintah maupun swasta, maka salah satunya harus memilih untuk keluar, dan biasanya perempuanlah yang memili keluar dari pekerjaan. Ini bagian dari faktor-faktor bias gender dalam bidang pendidikan.

3. Faktor struktural, yakni yang menyangkut nilai, sikap, pandangan, dan perilaku masyarakat yang secara dominan mempengaruhi keputusan keluarga untuk memilih jurusan-jurusan yang lebih dianggap cocok untuk perempuan, seperti pekerjaan perawat, kesehatan, teknologi kerumah-tanggaan, psikologi, guru sekolah dan 
sejenisnya. Hal ini terjadi karena perempuan dianggap hanya memilih fungsi-fungsi produksi (reproductive function). Laki-laki dianggap lebih berperan sebagai fungsi penopang ekonomi keluarga (productive function) sehingga harus lebih banyak memilih keahliankeahlian ilmu teknologi dan industri.

4. Pendidikan Islam yang konstruktif merupakan salah satu pendekatan pendidikan melalui pembelajaran induktif, yang berarti mengangkat nilai-nilai faktual empirik. Pendidikan reseptif yang hanya memperkuat hapalan, apabila hapalan itu hilang maka subyek didik tidak akan punya apa-apa lagi, maka diperlukan pendidikan yang demokratis yaitu peserta didik diberikan kesempatan untuk mengeluarkan pendapat, menyampaikan opini, dan mengeskpresikan kemampuan nalar, maka akan melahirkan komunitas intelektual yang cendekiawan.

\section{E. Kesimpulan}

Melihat kualitas kesetaraan gender di Indonesia dibidang pendidikan dapat dilihat dari tingkat kesetaraan dalam pendidikan, tingkat kesetaraan bagi laki-laki maupun perempuan dibidang pendidikan khususnya di Indonesia masih sangat menghawatirkan, pendidikan bagi perempuan di Indonesia masih sangat rendah dibandingkan kaum laki-laki. Jumlah anak perempuan yang tidak meneruskan pendidikan lanjutan pertama dan menengah sampai keperguruan tinggi lebih besar daripada murid laki-laki, selain itu ditambah angka putus sekolah yang tinggi serta masih tingginya angka diskriminasi, rendahnya angka lulusan perguruan tinggi pada kaum perempuan serta masih tingginya angka buta huruf di kalangan perempuan Indonesia masih sangat dominan, sehingga bila tidak ada upaya untuk memperbaikinya maka usaha pemerintah untuk menekan kemiskinan tidak akan berhasil. 
Jika diyakini bahwa pendidikan merupakan hak setiap orang baik laki-laki maupun perempuan, maka segala bentuk hambatan harus dihapuskan. Baik hambatan yang disebabkan kebijakan politik, nilai budaya, maupun pemikiran keagamaan, serta justifikasi atas otoritas yang didukung oleh perangkat Undang-undang negara, yang tentunya akibat ini semua sangat merugikan pihak kaum perempuan. Pendidikan merupakan hak setiap orang, baik laki-laki dan perempuan berhak atas pendidikan yang sama. Falsafah negara menempatkan setiap orang untuk setara, yang memiliki kesempatan yang sama dalam pendidikan. Oleh karena itu, Pemerintah Republik Indonesia harus cepat melakukan sebuah langkah atau kebijakan atas konstruk budaya yang sangat memarginalisasikan kaum hawa, khususnya ketidakadilan dalam ranah pendidikan. Politik hukum atau kebijakan hukum yang telah di lakukan oleh pemerintah Republik Indonesia sebagaimana yang telah dipaparkan di atas, dibentuk guna memberikan nilai keadilan dan kesetaraan gender dalam pendidikan.

Bentuk ketidak-adilan gender yang berupa proses marginalisasi perempuan adalah suatu pemiskinan atas satu jenis kelamin tertentu dalam hal ini disebabkan oleh perbedaan gender, ketidak-adilan gender menyebabkan ketidaknyamanan serta terbelenggunya hak kebebasan perempuan sebagai manusia (HAM). Ketidak-adilan gender banyak dipengaruhi oleh beberapa factor, seperti yang telah dipaparkan diatas, factor internal dan factor eksternal bahkan budaya patriarkhi yang mebudaya atau bahkan salah penafisran terhadap teks agama, yang mapan secara universal dan berlangsung selama berabad-abad, serta justifikasi atas otoritas yang didukung oleh perangkat Undang-undang negara, yang tentunya akibat ini semua sangat merugikan pihak kaum perempuan untuk menikmati hak pendidikan, hak untuk memperoleh pendidikan adalah hak yang harus terpenuhi. Oleh karena itu, segala bentuk ketidak-adilan, 
khususnya ketidak-adilan dalam pendidikan, merupakan pelanggaran hak asasi manusia (HAM), dan kajahatan terhadap martabat kemanusiaan serta bentuk diskriminasi yang wajib dihapuskan.

\section{Daftar Pustaka}

Nunuk P. Murti, Getar Gender, Magelang: Indonesia Tera, 2003

Santi Wijaya Hesti Utami, Kesetaraan Gender "Langkah Menuju Demokratisasi Desa, Yogyakarta: IP. Lappera Indonesia, 2001

Chatarina Mac Kinnon, Feminisme Unmodified, Harvard University Press, 1987

Coomans, "The Core Content of the Raights." dalam Brand dan Russel (ed.), Exploring teh Core Content of SocioEconomic Raghts, South African and International Perspectivis, (Pretoria, Protea book House, 2002

Elliot, S.N., Educational Psukology, Madison: Brown dan Benchmark, 1999

Franz Magnis Suseno, Etika Politik: Prinsip-Prinsip Moral Dasar Kenegaraan Modern (Jakarta: PT Gramedia Pustaka Utama, 2001

Frans Magnis Suseno, Etika Politik: Prinsip-Prinsip Dasar Kenegaraan Modern, (Jakarta: Gramedia Pustaka Utama, 1994

Franz Magnis Suseno, Etika Politik: Prinsip-Prinsip Moral Dasar Kenegaraan Modern Jakarta: PT Gramedia Pustaka Utama, 2001

Faqih, Mansour, Analsis Gender dan Transformasi Sosial, Yogyakarta: Pustaka Pelajar, 1999 
Faqihuddin Abdul Kodir, Bergerak Menuju Keadilan : Pembelaan Nabi Terhadap Perempuan, Jakarta: Rahima, 2006

Hasbullah, Sejarah Pendidikan Islam di Indonesia Lintas Sejarah Pertumbuhan dan Perkembangan, Jakarta: Raja Grafindo Persada, 1999

Haifaa A. Jawad, The Right of Women in Islam, Britain: Macmillan Press, 1998

Ihya' Ulu $>$ m ad-di $>$ n dan Imam Nawawi (w. 1315H) dalam kitab Uqu>d al-Lujjain. Lihat, FK3, Wajah Baru Relasi Suami Isteri: Telaah Kitab 'Uqu>d 1-Lujjayn, 2001

Imam Syaukani dan A. Hasan Thohari, Dasar-dasar Politik Hukum, Jakarta: Rajawali Pers, 2010

Margert Mead, Sex and Temperament in Three Primitive Societies, tp., 1935

Majda El-Muhtaj, Hak Asasi Manusia dalam Konstitusi Indonesia: Dari UUD 1945 Sampai dengan Amandemen UUD 1945 Tahun 2002, Jakarta: KENCANA, 2009 , Dimensi-Dimensi HAM "Mengurai Hak Ekonomi, Sosial dan Budaya, Jakarta: Rajawali Press, 2009

M. Afif Hasbullah, Politik Hukum Ratifikasi Konvensi HAM Di Indonesia "Upaya Mewujudkan Masyarakat Yang Demokratis", Yogyakarta: PUSTAKA PELAJAR, 2005

M.H., Syed, Human Raights; the Global Perspektiv, New Delhi, Reference Press, 2003

Musdah Mulia, Islam dan Hak Asasi Manusia "Konsep dan Implementasinya, Jakarta: Naufan Pustaka, 2010 
,Muslimah Reformis Perempuan Pembaru

Keagamaan. Cet. I. Bandung: Mizan, 2004.

Margaret Davies, Asking the Law Question, The Law Book Company Limited, 1994 Rusli, "The Tradisional and Women's Issues In The Shafi'ite Books of Islamic Jurisprudence", dalam Jurnal Asy-Syir'ah, Metode Penemuan Hukum Islam, vol. 38. No. II. Yogyakarta: UIN Suka, 2004

Riant Nugroho, Gender dan Adminstarsi Publik "StudynTentang Kualitas Kesetaraan Gender dalam Adminstrasi Publik Indonseian Pasca Reformasi 19982002, Yogyakarta: PUSTAKA PELAJAR, 2008

Sri Hastuti Puspitasari, "Perlindungan HAM dalam Struktur Ketatanegaraan Republik Indonesia, dalam, Eko Riyadi dan Supriyanto Abdi (Ed.), Mengurai Kompleksitas Hak Asasi Manusia "Kajian Multi Perspektif", Yogyakarta: PUSHAM UII, 2007

Sri Sundari Sasongko, Konsep dan Teori Gender, Jakarta: Pusat dan Pelatihan Gender dan Peningkatan Kualitas Perempuan Badan Kordinasi Keluarga Berencana Nasional, 2007

Suparman Marzuki, Eko Riyadi (Penyunting/Editor), Hukum Hak Asasi Manusia Yogyakarta: Pusat Studi Hak Asasi Manusia Universitas Islam Indonesia PUSHAM UII, 2008

Suparman Marzuki, Politik Hukum Hak Asasi Manusia (HAM) di Indinesia, disampaikan sebagai bahan bacaan mata kuliah Pilitik Hukum HAM, Program Megister Ilmu Hukum FH. UII. 2010

Sahbana, "Wanita Indonesia dalam Keluarga Persepektif Islam, dalam, Jurnal Ilmu Syari'ah, Keadilan Gender dalam Syari'at Islam, Yogyakarta: UIN Press, 2001 
Suryadi, Ace \& Ecep Idris. Kesetaraan Gender dalam Bidang Pendidikan. Cet. I. Bandung: Genesindo, 2004

Siti Ruhaini Dzuhayatin, Teologi Feminis Islam "Suatu Refleksi Pergulatan Pemikiran Feminis dalam Wacana Islam di Indonesia, Jurnal Teologi Gema, edisi 55

Sulastin Sutrisno, Surat-surat Kartini, Renungan Tentang dan Untuk Bangsanya, Jakarta: Djambatan, 1981

Suryadi, Ace \& Ecep Idris. Kesetaraan Gender dalam Bidang Pendidikan. Cet. I. Bandung: genesindo, 2004

Susilaningsing dan Agus Muh. Najib (Ed.), Kesetaraan Gender di Perguruan Tinggi Islam, Yogyakarta: UIN Suka dan McGill-IAIN, 2004 
258 Rinrin Rina: Hak-hak Pendidikan Kaum Perempuan....

Fikri, Vol. 2, No. 1, Juni 2017 